\title{
Methotrexate Inhibits Integrin Adhesion Molecules in the Mouse Model of Pleurisy Induced by Carrageenan
}

\author{
Eduardo Monguilhott Dalmarco ${ }^{1}$ and Tânia Silvia Fröde ${ }^{2 *}$ \\ ${ }^{1}$ Universidade Regional de Blumenau; Itoupava Seca; 89030-030; Blumenau - SC - Brasil. ${ }^{2}$ Universidade Federal de \\ Santa Catarina; Campus Universitário - Trindade, 88040-970, saleh@ccs.ufsc.br; Florianópolis - SC - Brasil.
}

\begin{abstract}
The aim of this work was to analyze the effect of methotrexate (MTX) upon leukocyte migration and expression of adhesion molecules CD11a/CD18 in the lung, 4 and $48 \mathrm{~h}$ after inflammation induction by carrageenan in mice. The results showed that MTX significantly decreased leukocyte influx and CD11a expression in the lung at 4 and $48 \mathrm{~h}$ of pleurisy $(P<0.01)$. MTX also inhibited CD18 expression at $4 \mathrm{~h}$ but not $48 \mathrm{~h}$ of pleurisy $(P<0.01)$. These results proved that MTX at the studied doses had important anti-inflammatory properties, acting primarily on leukocyte migration from the pleural cavity to the lung via inhibition of CD11a/CD18 expression in the mouse model of inflammation.
\end{abstract}

Key words: Methotrexate, CD11a/CD18 adhesion molecules, leukocyte migration, pleurisy, mice

\section{INTRODUCTION}

Methotrexate (MTX) was synthesized 50 years ago to obtain the competitive folic acid antagonist drug (Schnabel, 2001). This drug was initially used in tumor treatment and leukemia (Farber et al., 1956) and later as an anti-inflammatory or immunosuppressor drug (Seitz, 1999). MTX is also used in the treatment of refractory rheumatoid arthritis (RA) (Wakabayashi et al., 2003) and other chronic inflammatory diseases such as psoriasis, biliary cirrhosis, Crohn's disease or intrinsic asthma (Weinblatt et al., 1998; Genestier et al., 2000). Methotrexate is effective in the prophylaxis of acute graft- $v s$. -host disease (GVHD) when used either alone or with cyclosporin A and/or prednisone (Storb et al., 1986; Sullivan et al., 1989; Nash et al., 1992; Chao et al., 1993) or FK506 (Nash et al., 1996). MTX has also been used as an adjunct therapy for persistent mild cardiac allograft rejection (Olsen et al., 1990).

The mechanism through which MTX exerts its inhibitory effect on leukocyte migration is not known. Studies have revealed that MTX is taken up by cells and tissues and immediately converted to metabolites linked to glutamate (MTX-polyglutamate). The resulting complex is responsible for most of the biochemical and biological activities of methotrexate (Panetta et al., 2002). MTX-polyglutamate inhibits enzymes such as dihydrofolate-reductase (DHFR) and others that are dependent on folate. In addition, the drug appears to act on the biosynthesis of nucleotides (purine and pirimidine) (Budzik et al., 2000).

Many studies have addressed the anti-inflammatory effects of methotrexate, such as apoptosis and inhibition of T cell clones (Genestier et al., 2000), suppression of purine biosynthesis in mitogen-stimulated human T-lymphocytes

\footnotetext{
*Author for correspondence
} 
(Fairbanks et al., 1999), increase of anti-inflammatory cytokines release in vitro (Constantin et al., 1998; Seitz and Dayer, 2000; Sung et al., 2000), adenosine release in vivo and in vitro (Morabito et al., 1998; Montesinos et al., 2002) and inhibition of neutrophil migration in patients with rheumatoid arthritis (Kraan et al., 2000).

In this study the mouse model of pleurisy induced by carrageenan was studied. This model presents a biphasic inflammatory response in the mouse pleural cavity. In the early phase, a significant enhancement of leukocyte influx occurs due to neutrophils $4 \mathrm{~h}$ after carrageenan treatment. In the late phase, a significant increase of leukocytes is observed due to mononuclear cells $48 \mathrm{~h}$ after carrageenan administration (Saleh et al., 1996). These early and late responses are associated with a marked inflammatory reaction in the airways similar to that which occurs in human asthma.

Thus, the aim of this study was to analyze the anti-inflammatory effect of methotrexate upon leukocyte influx as well as expression of the CD11a/CD18 adhesion molecules in the lung in the experimental inflammation model induced by carrageenan in mice.

\section{MATERIAL AND METHODS}

\section{Animals}

Non-fasted adult Swiss mice of both sexes (18-25 g), aged 2 months were used throughout the experiments. They were housed in accordance with institutional animal care requirements (temperature $21 \pm 2^{\circ} \mathrm{C}$, under a light/dark cycle of $12 \mathrm{~h}$ ) and fed freely on standard rodent chow and water. The following groups of animals were studied: 1) pretreated and 2) untreated with methotrexate prior to the induction of pleurisy with carrageenan. In parallel, two or three animals that had received an injection of either sterile saline $(\mathrm{NaCl}, 0.9 \%)$ by intrapleural (i.pl.) route or methotrexate by intraperitoneal (i.p.) route were included in all experimental groups.

\section{Induction and analysis of pleurisy}

As previously described (Saleh et al., 1996), pleurisy was induced by a single intrapleural injection of $0.1 \mathrm{~mL}$ of sterile saline plus carrageenan $(1 \%)$. Since the pleurisy caused by carrageenan exhibits a biphasic nature $(4 \mathrm{~h}$ and 48 h), both interval-points were chosen to analyze the studied parameters.

Several samples of the lung were collected for further determination of both lung leukocyte influx and lung $\mathrm{CD} 11 \mathrm{a} / \mathrm{CD} 18$ adhesion molecule expression.

Thus, the doses chosen to analyze lung leukocyte influx as well as lung CD11a/CD18 adhesion molecule expression were $20 \mathrm{mg} / \mathrm{kg}$, i.p. administered 0.5 and $24 \mathrm{~h}$ before pleurisy $(4 \mathrm{~h})$ and $40 \mathrm{mg} / \mathrm{kg}$, i.p. $0.5 \mathrm{~h}$ before pleurisy $(48 \mathrm{~h})$ (Dalmarco et al., 2002).

\section{Lung Histology}

Following pleurisy induction, the lungs were removed, washed in phosphate buffered saline (PBS - pH 7.6: $\mathrm{NaCl} 137 \mathrm{mM}, \mathrm{KCl} 2 \mathrm{mM}$ and phosphate buffer $10 \mathrm{mM}$ ) and placed in $2 \mathrm{ml}$ of buffered formalin (10\%) for $48 \mathrm{~h}$. Than, the tissues were passed through serial concentrations of alcohol followed by xylene, and then embedded in paraffin and sectioned at 3 microns using a microtome (LEICA-Instruments, Nussloch, Germany). Hematoxylin-eosin sections were examined in a blinded fashion by a pathologist.

\section{Immunohistochemical analysis}

Immunostaining of lung sections obtained at 4 and $48 \mathrm{~h}$ after pleurisy induction was conducted using the DAKO Envision System (Dako, Carpinteria, CA, USA) according to the manufacturer's instructions. In brief, endogenous peroxidase activity was blocked with distilled water and the sections and slides were incubated for $1 \mathrm{~h}$ with primary antibody against rat anti-mouse CD11a or CD18 (Sigma-Aldrich, St. Louis, Missouri, USA) diluted 1:50 in TRIS-HCL buffer (composition: TRIS $13.9 \mathrm{~g}$; TRIS-HCL $60.6 \mathrm{~g}, \mathrm{NaCl} 87.66 \mathrm{~g}, \mathrm{pH}$ 7.6) at $36-37^{\circ} \mathrm{C}$ in a humid chamber. After two washes in automation buffer (PBS), the sections were incubated with secondary antibody $\operatorname{IgG} / \operatorname{IgM}$ (DAKO, Carpinteria, California, USA) for $25 \mathrm{~min}$ at room temperature in a humid chamber. The slides were incubated with peroxidase - conjugate (Dako, Carpinteria, CA, USA) for $25 \mathrm{~min}$ at room temperature in a humid chamber. Following another wash in automation buffer, sections were incubated in the chromogen DAB(diaminobenzidine; Dako). Counterstaining was performed with hematoxylin and examined in a blind fashion by a pathologist. 


\section{Drugs and reagents}

The following drugs and reagents were used: methotrexate (Wyent, São Paulo, São Paulo, Brazil); ethyl alcohol $\left(70^{\circ}, 80^{\circ}, 95^{\circ}\right.$ and PA), methyl alcohol, yellow eosin, paraffin, formol (Synth, Barueri, São Paulo, Brazil); carrageenan lambda (grade IV), monoclonal rat anti-mouse CD11a and CD18 (Sigma-Aldrich, St. Louis, Missouri, USA); TRIS-HCL buffer (TRIS - pH 7.6: 13.9 g; TRIS-HCL $60.6 \mathrm{~g}, \mathrm{NaCl} 87.66 \mathrm{~g}$ ), phosphate buffered saline (PBS - pH 7,6: $\mathrm{NaCl} 137 \mathrm{mM}, \mathrm{KCl}$ $2 \mathrm{mM}$ and phosphate buffer $10 \mathrm{mM}$ ), hematoxylin, xylene, Entellan (Merck, Armstard, Germany); diaminobenzidine (DAB) (ACROS-Organics, New Jersey, USA); ethyl ether (Dinamica, São Paulo, São Paulo, Brazil); saline (NaCl 0.9\%) (Sanoclear, Pouso Alegre, Minas Gerais, Brazil); IgG/IgM secondary antibodies, streptavidin-biotin-peroxidase (DAKO, Carpinteria, California, USA).

\section{Statistical Analysis}

Statistical differences between groups (control and inflamed animals) were determined by Kruskal-Wallis and Dunn tests. Differences were considered significant at $\mathrm{P}<0.05$.

\section{RESULTS}

In all figures, panels $\mathrm{A}$ and $\mathrm{B}$ represent control groups: $\mathrm{A}=$ Saline- treated animals and $\mathrm{B}=$ Carrageenan-treated animals.

\section{Effect of methotrexate upon lung cell influx in animals with pleurisy}

In the early phase $(4 \mathrm{~h})$, methotrexate (MTX; 20 $\mathrm{mg} / \mathrm{kg}$, i.p.) administered 0.5 and $24 \mathrm{~h}$ before carrageenan injection significantly decreased the congestion between the septal wall in the lung alveolar $(\mathrm{P}<0.01)$. Furthermore, this treatment reduced lung neutrophilic infiltration $(\mathrm{P}<0.01)$ (Table 1 and Fig. 1, panels C and D).

Table 1 - Lung Histological Injury Scores in methotrexate-treated animals ( $20 \mathrm{mg} / \mathrm{kg}$, i.p.) in the early phase (4 h) of the inflammatory response induced by carrageenan.

\begin{tabular}{lccc}
\hline \multicolumn{1}{c}{ Histological Analysis } & Control & Methotrexate & Significance \\
\hline Lung alveolar septal wall congestion & 3 & 2 & $\mathrm{P}<0.01$ \\
Neutrophils sequestration & 3 & 1 & $\mathrm{P}<0.01$ \\
Mononuclears sequestration & 3 & 1 & $\mathrm{P}<0.01$ \\
\hline
\end{tabular}

Controls are results obtained in carrageenan-treated animals in the early phase $(4 \mathrm{~h})$ of inflammation. Scores are on a scale of 0 to 3 , with $0=$ none, $1=$ mild, $2=$ moderate, and $3=$ severe in accordance with Motohiro et al. (1986); Lossos et al. (2000). At least 3-4 slides of a pool of experiments were analyzed.

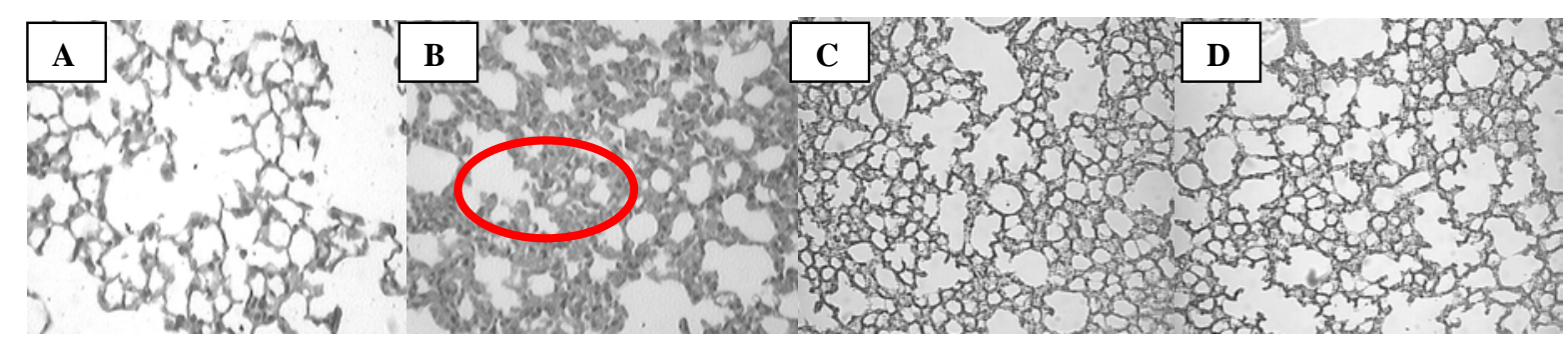

Figure 1 - Comparative analysis of mouse lung sections in the early phase $(4 \mathrm{~h})$ of the inflammatory response induced by carrageenan (Cg 1\%/cav.) A- Saline-treated animals. BCarrageenan-treated animals. Effect of methotrexate $(20 \mathrm{mg} / \mathrm{kg}$, i.p. $)$, administered $0.5 \mathrm{~h}$ (C) or $24 \mathrm{~h}$ (D) before carrageenan, upon inflammatory parameters observed in Table 1. Positive staining is indicated by circle (magnification of $200 \mathrm{x}$ )

In the late phase (48 h), MTX (40 mg/kg, i.p.) administered $0.5 \mathrm{~h}$ before pleurisy induction significantly decreased neutrophils and mononuclears in the lung $(\mathrm{P}<0.01)$. MTX also decreased the lung alveolar septal wall 
congestion $48 \mathrm{~h}$ after $(\mathrm{P}<0.01)$ (Table 2 and Fig.

2, panel C).

Table 2 - Lung Histological Scores in methotrexate-treated animals (40 mg/kg, i.p.) in the late phase (48 h) of the inflammatory response induced by carrageenan.

\begin{tabular}{lccc}
\hline \multicolumn{1}{c}{ Histological Analysis } & Control & Methotrexate & Significance \\
\hline Lung alveolar septal wall congestion & 3 & 2 & $\mathrm{P}<0.01$ \\
Neutrophils sequestration & 3 & 1 & $\mathrm{P}<0.01$ \\
Mononuclears sequestration & 3 & 1 & $\mathrm{P}<0.01$ \\
\hline
\end{tabular}

Controls are results obtained in carrageenan-treated animals in the late phase $(48 \mathrm{~h})$ of inflammation. Scores are on a scale of 0 to 3 , with $0=$ none, 1 = mild, 2 = moderate, and 3 = severe in accordance with Motohiro et al. (1986); Lossos et al. (2000). At least 3-4 slides of a pool of experiments were analyzed.

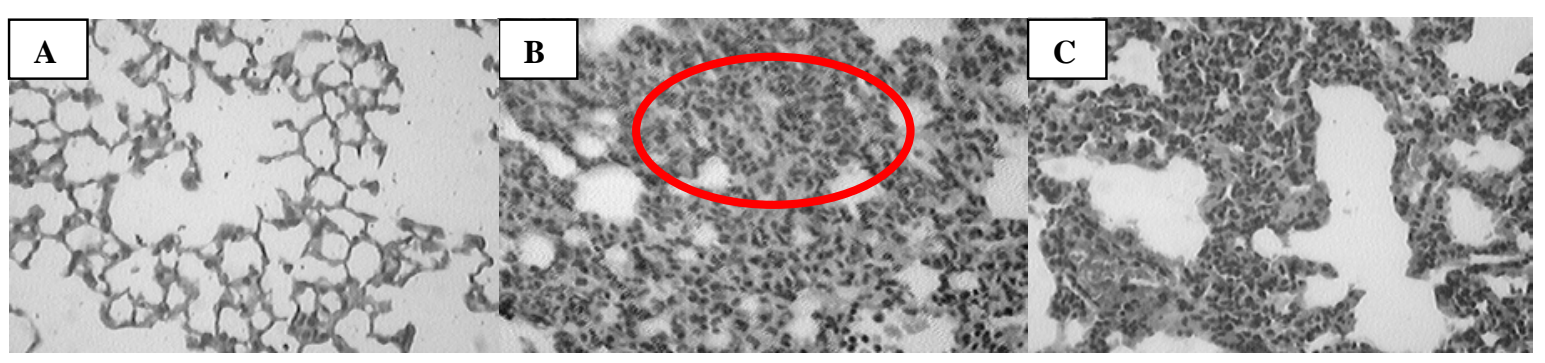

Figure 2 - Comparative analysis of mouse lung sections in the late phase $(48 \mathrm{~h})$ of the inflammatory response induced by carrageenan (Cg 1\%/cav.) A- Saline-treated animals. BCarrageenan-treated animals. Effect of methotrexate (40 mg/kg, i.p.), administered $0.5 \mathrm{~h}$ (C) before carrageenan, upon inflammatory parameters observed in table 2. Positive staining is indicated by circle (magnification of $200 \mathrm{x}$ )

\section{Effect of methotrexate upon lung significantly decreased lung CD11a expression CD11a/CD18 adhesion molecules expression in animals with pleurisy $(\mathrm{P}<0.01)$ (Fig. 3, panels C) and CD18 (Fig. 4, panels $\mathrm{C}$ and $\mathrm{D}$ ).}

In the early phase $(4 \mathrm{~h})$, MTX $(20 \mathrm{mg} / \mathrm{kg}$, i.p. $)$ administered 0.5 or $24 \mathrm{~h}$ before carrageenan ,



Figure 3 - Comparative analysis of CD11a expression in lung sections in the early phase (4 h) of the inflammatory response induced by carrageenan (Cg 1\%/cav.) A- Saline-treated animals. B- Carrageenan-treated animals. Effect of methotrexate $(20 \mathrm{mg} / \mathrm{kg}$, i.p.), administered $0.5 \mathrm{~h}(\mathrm{C})$ or $24 \mathrm{~h}$ (D) before carrageenan, upon CD11a expression in lung. Positive staining is indicated by circle (magnification of $400 \mathrm{x}$ ) 


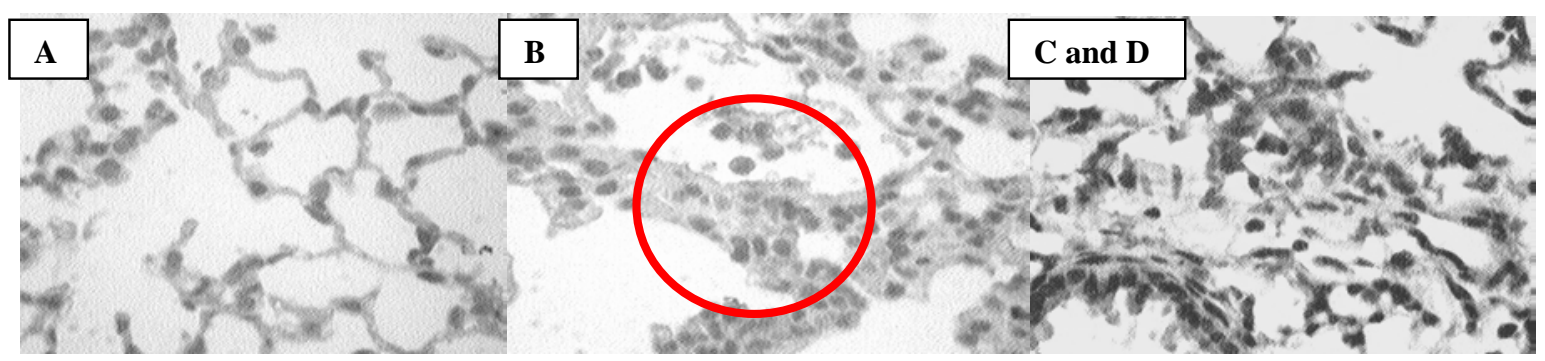

Figure 4 - Comparative analysis of CD18 expression in lung sections in the early phase $(4 \mathrm{~h})$ of the inflammatory response induced by carrageenan (Cg 1\%/cav.) A-Saline-treated animals. B- Carrageenan-treated animals. Effect of methotrexate $(20 \mathrm{mg} / \mathrm{kg}$, i.p. $)$, administered $0.5 \mathrm{~h}(\mathrm{C})$ or $24 \mathrm{~h}$ (D) before carrageenan, upon CD18 expression in lung. Positive staining is indicated by circle (magnification of $400 \mathrm{x}$ )

In the late phase $(48 \mathrm{~h})$, this drug $(40 \mathrm{mg} / \mathrm{kg}$, i.p.) administered $0.5 \mathrm{~h}$ before carrageenan administration inhibited lung CD11a $(\mathrm{P}<0.01)$
(Fig. 5, panel C), but not CD18 expression (P > 0.05) (Data not shown).

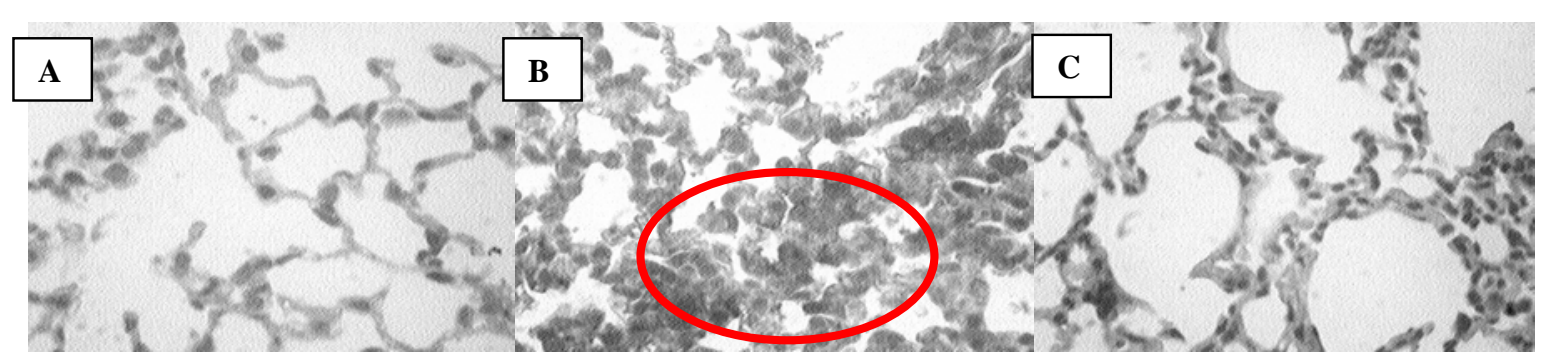

Figure 5 - Comparative analysis of CD11a expression in lung sections in the late phase (48 h) of the inflammatory response induced by carrageenan $(\mathrm{Cg} 1 \% / \mathrm{cav}.) \mathrm{A}-$ Saline-treated animals. B-Carrageenan-treated animals. Effect of methotrexate ( $40 \mathrm{mg} / \mathrm{kg}$, i.p.), administered 24 $\mathrm{h}(\mathrm{C})$ before carrageenan, upon CD11a expression in lung. Positive staining is indicated by circle (magnification of $400 \mathrm{x}$ )

\section{DISCUSSION}

The present data demonstrated that methotrexate was able to reduce the two pools of leukocyte populations that migrated from the pleural cavity to the lung at distinct periods of time $(4 \mathrm{~h}$ and $48 \mathrm{~h}$ ) after induction of mouse pleurisy with carrageenan. This inhibition of lung cell influx was associated with a marked reduction of both CD11a and CD18 adhesion molecules expression. These results were in agreement with other studies that have shown that immunosuppressor drugs such as cyclosporin A inhibited the leukocyte influx in a number of experimental models, including rat arthritis induced by collagen (Oliver et al., 1995), rat cardiac allografts (Ciesielski et al., 1998), and mouse pneumonia induced by Escherichia coli (Wang et al., 2002). Furthermore, immunosuppressor drugs caused a significant inhibition of the lymphocytes sensitized by tuberculin in the guinea-pig (Winkelstein, 1975). Other authors have reported that methotrexate inhibited neutrophil chemotaxis in rheumatoid arthritis patients (O'callaghan et al., 1988; Kraan et al., 2000). This drug has also been found to present important antileukemic effects in in vivo studies (Dervieux et al., 2002).

There are few studies demonstrating the inhibitory effect of immunosuppressor drugs upon leukocyte migration. In vitro studies have shown that cyclosporin A (CLPA) inhibited intercellular adhesion molecule-1 (ICAM-1), vascular adhesion 
molecule-1, (VCAM-1), E-selectin, P-selectin, platelet/endothelial cell adhesion molecule-1 (PECAM-1) and the L-selectin ligand CD34 in human endothelial cells (Markovic et al., 2002; Rafiee et al., 2002; Zhou et al., 2004). CLPA reduced also endothelial and keratinocyte ICAM-1 expression in patients with psoriasis (Servitje et al., 1996).

The present model, methotrexate inhibited CD11a expression at 4 and $48 \mathrm{~h}$ after pleurisy induction and CD18 at $4 \mathrm{~h}$ after. Yamasaki et al. (2003) showed that methotrexate inhibited ICAM-1 and VCAM-1 in cultured human umbilical vein endothelial cells. Other studies have reported that methotrexate significantly decreased the E-selectin, ICAM-1 and VCAM-1 levels in bullous pemphigoid patients (Dahlman-Ghozlan et al., 2000). The findings showed that methotrexate caused a significant reduction in CD11a in both phases ( 4 and $48 \mathrm{~h}$ ) and CD18 in the early phase (4 h) of this inflammatory reaction added support to the hypothesis that the anti-inflammatory effects of methotrexate upon cell-cell adhesion were due to inhibition of CD11a molecules function.

The fact that CD18 was not inhibited by methotrexate in the late phase $(48 \mathrm{~h})$ suggested that this molecule did not have a central role in the chemotaxis of mononuclear cells in the late phase $(48 \mathrm{~h})$ of the inflammatory process induced by carrageenan in mice. According to these results, the hypothesis regarding the participation of CD18 in this inflammatory response could not be discarded, because MTX decreased the CD18 expression in the early phase $(4 \mathrm{~h})$ of the inflammatory process induced by carrageenan.

In summary, this work presented evidence that the inhibitory effect of methotrexate upon both neutrophil and mononuclear cells was associated with an inhibition of integrin adhesion molecules priory CD11a. The results regarding the expression of adhesion molecule CD18 indirectly contributed to this anti-inflammatory effect. Taken together, these data indicated that the anti-inflammatory effects of methotrexate upon leukocyte migration occurred via different mechanisms and were possibly dependent on the model of inflammation.

\section{ACKNOWLEDGMENT}

This study was supported by grants from the Conselho Nacional de Desenvolvimento Científico e Tecnológico (CNPq) and FUNPESQUISA
(Fundação de amparo a pesquisa e extensão-Universidade Federal de Santa Catarina (UFSC), Brazil.

\section{RESUMO}

O modelo experimental da pleurisia induzida pela carragenina, em camundongos é caracterizado pelo aumento da migração de leucócitos às custas de neutrófilos $4 \mathrm{~h}$ após a indução da inflamação pela carragenina na cavidade pleural de camundongos.. Após $48 \mathrm{~h}$ da indução da inflamação ocorre aumento de leucócitos do tipo mononucleares. O objetivo deste trabalho foi avaliar o efeito do metotrexato (MTX) sobre a migração de leucócitos, e a expressão de moléculas de adesão (CD11a/CD18), no pulmão 4 e $48 \mathrm{~h}$ após a inflamação induzida pela carragenina.Os resultados demonstraram que o MTX inibiu significativamente o influxo de leucócitos e a expressão de CD11a no pulmão 4 h e 48 h após a inflamação induzida pela carragenina $(\mathrm{P}<0.01)$. $\mathrm{O}$ MTX inibiu a expressão de CD18 no pulmão $48 \mathrm{~h}$ após, mas não $4 \mathrm{~h}$ após esta resposta inflamatória $(\mathrm{P}<0.01)$. Estes resultados demonstram que o MTX, nas doses estudadas, possui importante efeito antiinflamatório agindo principalmente sobre o influxo de leucócitos da cavidade pleural para os pulmões, via inibição da expressão de moléculas de adesão do tipo CD11a/CD18, no modelo da pleurisia induzida pela carragenina, em camundongos.

\section{REFERENCES}

Budzik, G. P.; Colletti, L.M.; Faltynek, C. R. (2000), Effects of methotrexate on nucleotide pools in normal human T cells and the CEM T cell line. Life Sci., 66, 2297-2307.

Chao, N. J., Schmidt, G. M., Niland, J. C., Amylon, M. D., Dagis, A. C., Long, G. D., Nademanee, A. P., Negrin, R. S., O'Donnell, M. R., Parker, P. M., Smith, E. P., Snyder, D. S., Stein, A. S., Wong, R. M., Blume, K. G. and Forman, S. J. (1993), Cyclosporine, methotrexate, and prednisone compared with cyclosporine and prednisone for prophylaxis of acute graft-vs.-host disease. N. Engl. J. Med., 329, 1225-1230.

Ciesielski, C. J., Mei, J.; Piccinini, L. A. (1998), Effects of cyclosporine $\mathrm{A}$ and methotrexate on CD18 expression in recipients of rat cardiac allografts. Transpl Immunol., 6, 122-33. 
Constantin, A.; Loubet-Lescoulie, P.; Lambert, N.; Yassine-Diab, B.; Abbal, M.; Mazieres, B.;De Preval, C.; Cantagrel, A. (1998), Antiinflammatory and immunoregulatoryaction of methotrexate in the treatment of rheumatoid arthritis: evidence ofincreased interleukin-4 and interleukin-10 gene expression demonstrated in vitro by competitive reverse transcriptase-polymerase chain reaction. Arthritis Rheum., 41, 48-57.

Dahlman-Ghozlan, K.; Heilborn, J. D.; Stephansson, E. (2000), Circulating levels of soluble E-selectin, ICAM-1 and VCAM-1 in bullous pemphigoid during low-dose methotrexate therapy. A prospective study. Exp Dermatol., 9, 336-340.

Dalmarco, E. M.; Frode, T. S.; Medeiros, Y. S. (2002), Effects of methotrexate upon inflammatory parameters induced by carrageenan in the mouse model of pleurisy. Mediators Inflamm., 11, 299-306.

Dervieux, T.; Brenner, T. L.; Hon, Y. Y.; Zhou, Y.; Hancock, M. L.; Sandlund, J. T.; Rivera, G. K.; Ribeiro, R. C.; Boyett, J. M.; Pui, C. H.; Relling, M. V.; Evans, W. E. (2002), De novo purine synthesis inhibition and antileukemic effects of mercaptopurine alone or in combination with methotrexate in vivo. Blood., 100, 1240-1247.

Fairbanks, L. D.; Ruckemann, K.; Qiu, Y.; Hawrylowicz, C. M.; Richards, D. F.; Swaminathan, R.; Kirschbaum, B.; Simmonds H. A. (1999), Methotrexate inhibits the first committed step of purine biosynthesis in mitogen-stimulated human T-lymphocytes: a metabolic basis for efficacy in rheumatoid arthritis? Biochem J., 342, 143-152.

Farber, S., Toch, R., Sears, E. and Pinkel, D., 1956. Advances in chemotherapy of cancer in man. In: Advances in Cancer Research, Greenstein, H.A., Editor, 1956., Academic Press, New York, pp. 2-73.

Genestier, L.; Paillot, R.; Quemeneur, L.; Izeradjene, K.; Revillard, J. P. (2000), Mechanisms of action of methotrexate. Immunopharmacology, 47, 247-257.

Kraan, M. C.; De Koster, B. M.; Elferink, J. G.; Post, W. J.; Breedveld, F. C.; Tak, P. P. (2000), Inhibition of neutrophil migration soon after initiation of treatment with leflunomide or methotrexate in patients with rheumatoid arthritis: findings in a prospective, randomized, double-blind clinical trial in fifteen patients. Arthritis Rheum., 43, 1488-1495.

Lossos, I. S.; Izbicki, G.; Or, R.; Goldstein, R. H.; Breuer, R. (2000), The effects of suramin on bleomycin-induced lung injury. Life Science., 67, 2873-2881.

Markovic, S.; Raab, M.; Daxecker, H.; Griesmacher, A.; Karimi, A.; Muller, M. M. (2002) In vitro effects of cyclosporin $\mathrm{A}$ on the expression of adhesion molecules on human umbilical vein endothelial cells. Clin Chim Acta., 316, 25-31.
Montesinos, M. C.; Yap, J. S.; Desai, A.; Posadas, I.; Mccrary, C. T.; Cronstein, B. N. (2002), Reversal of the antiinflammatory effects of methotrexate by the nonselective adenosine receptor antagonists theophylline and caffeine: evidence that the antiinflammatory effects of methotrexate are mediated via multiple adenosine receptors in rat adjuvant arthritis. Arthritis Rheum., 43, 656-663.

Morabito, L.; Montesinos, M. C.; Schreibman, D. M.; Balter, L.; Thompson, L. F.; Resta, R.; Carlin, G.; Huie, M. A.; Cronstein, B. N. Methotrexate and sulfasalazine promote adenosine release by a mechanism that requires ecto-5'-nucleotidase -mediated conversion of adenine nucleotides. J Clin Invest., 101: 295-300, 1998.

Motohiro, A.; Furukawa, K.; Yasumoto, K.; Inokuchi, K. (1986), Mechanisms involved in acute lung edema induced in dogs by oleic acid. Eur Surg Res., 18, 50-57.

Nash, R. A., Pepe, M. S., Storb, R., Longton, G., Pettinger, M., Anasetti, C., Appelbaum, F. R., Bowden, R. A., Deeg, H .J., Doney, K., Martin, P. J., Sullivan, K. M., Sanders, J., Witherspoon, R. P. (1992), Acute graft-vs.-host disease: analysis of risk factors after allogeneic marrow transplantation and prophylaxis with cyclosporine and methotrexate. Blood, 80, 1838-1845.

Nash, R. A.; Pineiro, L. A.; Storb, R.; Deeg, H. J.; Fitzsimmons, W. E.; Furlong, T.; Hansen, J.A.; Gooley, T.; Maher, R. M.; Martin, P.; McSweeney, P. A.; Sullivan, K. M.; Anasetti, C.; Fay, J. W. (1996), FK506 in combination with methotrexate for the prevention of graft-versus-host disease after marrow transplantation from matched unrelated donors. Blood. 88, 3634-3641.

O'callaghan, J. W.; Forrest, M. J.; Brooks, P. M. (1988), Inhibition of neutrophil chemotaxis in methotrexate-treated rheumatoid arthritis patients. Rheumatol Int., 8, 41-45.

Oliver, S. J.; Cheng, T. P.; Banquerigo, M. L.; Brahn, E. (1995), Suppression of collagen-induced arthritis by an angiogenesis inhibitor, AGM-1470, in combination with cyclosporin: reduction of vascular endothelial growth factor (VEGF). Cell Immunol., 166, 196-206.

Olsen, S. L., O'Connell, J. B., Bristow, M. R., Renlund, D.G. (1990), Methotrexate as an adjunct in the treatment of persistent mild cardiac allograft rejection. Transplantation, 50, 773-775.

Panetta, J. C.; Yanishevski, Y.; Pui, C. H.; Sandlund, J. T.; Rubnitz, J.; Rivera, G. K.; Ribeiro, R.; Evans, W. E.; Relling, M. V.(2002), A mathematical model of in vivo methotrexate ccumulation in acute lymphoblastic leukemia. Cancer Chemother Pharmacol., 50, 419-428. 
Rafiee, P.; Johnson, C. P.; Li, M. S.; Ogawa, H.; Heidemann, J.; Fisher, P. J.; Lamirand, T. H.; Otterson, M. F.; Wilson, K. T.; Binion, D. G. (2002), Cyclosporine A enhances leukocyte binding by human intestinal microvascular endothelial cells through inhibition of p38 MAPK and iNOS. Paradoxical proinflammatory effect on the microvascular endothelium. J Biol Chem., 277, 35605-35615.

Saleh, T. S. F.; Calixto, J. B.; Medeiros, Y. S. (1996), Anti-inflammatory effects of theophylline, cromolyn and salbutamol in a murine model of pleurisy. $B r . J$. Pharmacol., 118, 811-819.

Schnabel, A. (2001), Methotrexate: Mechanisms of action, pharmacology and toxicology. In: Immunosuppression in inflammatory bowel diseases standards, new developments, future trends. Dordrecht, Germany, pp. 113-118.

Seitz, M., (1999), Molecular and cellular effects of methotrexate. Curr Opin Rheumatol., 11, 226-232, 1999.

Seitz, M.; Dayer, J.M. (2000), Enhanced production of tissue inhibitor of metalloproteinases by peripheral blood mononuclear cells of rheumatoid arthritis patients responding to methotrexate treatment. Rheumatology, 39, 637-645.

Servitje, O., Bordas, X., Seron, D., Vidaller, A., Moreno, A., Curco, N., Sais, G., Peyri, J., (1996), Changes in T-cell phenotype and adhesion molecules expression in psoriatic lesions after low-dose cyclosporin therapy. J Cutan Pathol., 23: 431-436.

Storb, R., Deeg, H. J., Whitehead, J., Appelbaum, F., Beatty, P., Bensinger, W., Buckner, D., Clift, R., Doney, K., Farewell, V., Hansen, J., Hill, R., Lum, L., Martin, P., McGuffin, R., Sanders, J., Stewart, P., Sullivan, K., Witherspoon, R., Yee, G., Thomas, E.D., (1986), Methotrexate and cyclosporine compared with cyclosporine alone for prophylaxis of acute graft-vs.-host disease after marrow transplantation for leukemia. N. Engl. J. Med., 314, 729-735.

Sullivan, K. M., Storb, R., Buckner, D., Ferer, A., Fisher, L., Weiden, P. L., Witherspoon, R. P., Appelbaum, F. R., Banaji, M., Hansen, J., Martin, P., Sanders, J. E., Singer, J., Thomas, D. (1989), Graft-versus-host disease as adoptive immunotherapy in patients with advanced hematologic neoplasms. N. Engl. J. Med., 320, 828-834.

Sung, J. Y.; Hong, J. H.; Kang, H. S.; Choi, I.; Lim, S. D.; Lee, J. K.; Seok, J. H.; Lee, J H.; Hur, G. M. (2000), Methotrexate suppresses the interleukin-6 induced generation of reactive oxygen species in the synoviocytes of rheumatoid arthritis. Immunopharmacology., 47, 35-44.

Wakabayashi, T.;Jackson, K.; Yamada, C.; Suzuki, Y.; Suzuki, Y. (2003), [Inhibition of joint destruction by Methotrexate.] Clin Calcium. 13: 764-770.
Wang, Q.;Teder, P.; Judd, N. P.; Noble, P. W.; Doerschuk, C. M. (2002), Cd44 deficiency leads to enhanced neutrophil migration and lung injury in Escherichia coli pneumonia in mice. Am J Pathol., 161, 2219-2228.

Weinblatt, M. E.; Maier, A. L.; Fraser, P. A.; Coblyn, J. S. (1998), Long-term prospective study of methotrexate in rheumatoid arthritis: conclusion after 132 months of therapy. J Rheumatol., 25, 238-242.

White, J. C. (1981), Recent concepts on the mechanism of action of methotrexate. Cancer Treat. Rep. 65, 3-12.

Winkelstein, A. (1975), Effects of cytotoxic immunosuppressants on tuberculin-sensitive lymphocytes in guinea pigs. $J$ Clin Invest., 56, 1587-1596.

Yamasaki, E., Soma, Y., Kawa, Y., Mizoguchi, M. (2003), Methotrexate inhibits proliferation and regulation of the expression of intercellular adhesion molecule- 1 and vascular cell adhesion molecule- 1 by cultured human umbilical vein endothelial cells. $\mathrm{Br} J$ Dermatol., 149: 30-38.

Zhou, S. G, Xu L. P., Liao, D. F., Lei, X. Y., Yan, F. X., Zhu, B. Y. (2004), [Cyclosporin A inhibits the adhesion of neutrophil with ECV-304 induced by hypoxia/ reoxygenation via ROS-Cyclophilin A-ERK1/2 pathway] Sheng Li Xue Bao., 56: 313-320.

Received: April 12, 2005; Revised: October 03, 2006; Accepted: April 04, 2007. 